\title{
TEATRO OFICINA ATENTO AO MOMENTO POLÍTICO
}

- RESUMO: Exame da trajetória do Teatro Oficina de São Paulo (1958-1972), no que concerne à sua preocupação de militância política. Por meio de encenações como $O$ rei da vela e Galileu Galilei, o Teatro Oficina demonstra rara sensibilidade para captar as angústias sociais de cada momento, detectando o texto que melhor expressa essa inquietação.

- PALAVRAS-CHAVE: Estética; teatro brasileiro; Teatro Oficina.

\section{Em busca de identidade social}

O Grupo Teatro Oficina, de São Paulo, desempenha um papel de vanguarda cultural, nas décadas de 1960 e 1970, renova a linguagem cênica em múltiplos aspectos, acrescenta dados críticos para uma nova consciência social e política brasileira e explicita os traços fundamentais de nossa identidade de país de mestiços e imigrantes, em busca de emancipação, num mundo regrado pelo capital internacional e pelas tensões ideológicas entre as grandes potências. Influenciado pelas correntes norte-americanas e européias, o grupo absorve, depura e nacionaliza conceitos, métodos e conquistas do teatro contemporâneo, em vital sintonia com o que se passa no planeta. Num quadro cultural dominado pela mer-

1 Departamento de Comunicação e Expressão - Instituto de Artes - UNESP - 04266-30 - São Paulo - SP. 
cadoria estrangeira, que tende a formar gostos, moldar opiniões e hábitos de consumo, impor modelos de comportamento e sistemas de vida, o Grupo Oficina restitui às platéias brasileiras o direito de se reconhecer em nossos palcos, exibe os traços dolorosos do subdesenvolvimento e da dependência e estilhaça a imagem mistificada e cômoda, fabricada para nos ludibriar e submeter.

O grupo nasce de uma certa consciência social pequeno-burguesa, investiga seus problemas pessoais e se aproxima, progressivamente, da visão crítica ampla de Bertolt Brecht. Ao mesmo tempo, crescem a tensão e a repressão políticas até a promulgação do AI-5, que coincide com a estréia de Galileu Galilei, de Brecht, pelo Oficina, em 13 de dezembro de 1968. A asfixia do momento subseqüente compele o grupo a uma explosão anárquica e irreprimível dos sentidos, uma afirmação dos instintos vitais, expressa na montagem de Na selva das cidades, do jovem Brecht, em 1969. À lucidez oportuna do dramaturgo o encenador amalgama a violência dos procedimentos sugeridos por Antonin Artaud e Jerzy Grotovski. As duas montagens, antropofágicas, espelham comportamentos-símbolos da sociedade brasileira, num esforço de reconhecer aspectos de nossa identidade cultural e histórica.

O Oficina recorre a peças estrangeiras, produzidas em outras circunstâncias culturais. Mas a leitura que seus integrantes realizam desses textos estrangeiros consegue vertê-los em diálogo nacional e crítico sobre o palco, diante de platéias brasileiras ávidas de informações sobre a realidade. Palavras e situações criadas pelo dramaturgo ganham materialidade física, atualidade e oportunidade em nosso país, nesse momento. O papel de vanguarda do Grupo Oficina entre nós decorre, aliás, de um impulso mais abrangente de certa produção cultural brasileira direcionada para o reconhecimento e a afirmação de nossa identidade, no confronto com a produção artística internacional. Duas vertentes de idéias parecem fundir-se aqui: o imperativo histórico de análise da realidade brasileira com o objetivo pragmático de nela fincar os pés e transformá-la, e a tendência de universalização da cultura, um ideal muito freqüentemente contestado, porque abriria espaços para a dominação cultural dos países pobres pelos ricos, afirmavam alguns.

\section{Aventura de autoconhecimento}

Com crescente garra antropofágica, o Grupo Oficina se atira sobre as obras de alguns monstros sagrados do teatro contemporâneo, sem nenhum respeito castrador. Deglutidas, tornam-se viáveis, nítidas e oportu- 
nas à reflexão do espectador brasileiro, graças ao trabalho de recriação dos encenadores.

Processo de dessacralização, transculturação e transvaloração, que engendra novos significados. Do confronto entre as situações e os personagens da ficção teatral e os seus homólogos do aqui e do agora, nascem luzes críticas que enriquecem o pensamento das novas gerações de espectadores, principalmente entre os estudantes universitários. E requer uma operação mental elaborada, capaz de proceder a generalizações, de compensar as distorções do espelho, de dialogar com as elipses, as alegorias e as analogias; reconhecer o deslocamento dos eixos dogmáticos e tradicionais de pensamento e referência; identificar o outro em si e vice-versa. E fazer das ambigüidades uma fonte pródiga de novas aquisições intelectuais, de jogos estimulantes de análises e sínteses, que conduzem o público ao enfrentamento de sua realidade subdesenvolvida e dependente, faminta e amedrontada.

Essa aventura social, intelectual e estética não pôde frutificar amplamente em todos os setores da sociedade brasileira por outras razões compreensíveis, que a condição de dependência e subdesenvolvimento explica: os preços proibitivos que impedem o acesso das camadas menos favorecidas a esse tipo de produção cultural. Razão que priva o Oficina de dialogar e crescer no contato com esse tipo de público e restringe o conhecimento de seu repertório à pequeno-burguesia urbana, reiterando um condicionamento que orienta o seu foco de atenção sobre as atitudes sociais dessa mesma classe e sua virtual capacidade de se transformar e conduzir o próprio destino e o do país.

Insatisfeito com os triunfos já obtidos e atento aos berros da realidade brasileira, o grupo está sempre revendo seus resultados e cada nova proposta contesta e devora o sucesso anterior. Antropofágicos e autofágicos, embarcados numa aventura de autoconhecimento, os integrantes do Oficina querem captar o comportamento do homem brasileiro, para plasmá-lo na cena. Na busca desse retrato, as satisfações parciais levam-nos ao processo de identificação com dramaturgos e teatrólogos estrangeiros como Sartre, Odets, Gorki, Frisch, Brecht, Artaud e Grotovski. Um feixe de contestações universalistas aos valores éticos do capitalismo e às instituições do Ocidente.

\section{Retrato evolutivo da pequeno-burguesia e simpatias heterogêneas}


Ao iniciar suas atividades em 1958, um grupo de estudantes universitários vive as contradições típicas dos jovens de classe média urbana, que anseiam por uma libertação existencial, longe dos cerceamentos da moral e da convivência familiar, pequeno-burguesa, maravilhada com o período promissor e feliz do desenvolvimentismo juscelinista, que amplia as portas do Brasil para a penetração do capital, da cultura, da arte e das modas internacionais. Alimenta-se a esperança de novos empregos, de outro nível de conforto trazido pela tecnologia, de redenção econômica, de saída do subdesenvolvimento e de nossa entrada definitiva no concerto das nações progressistas, cultas e abastadas do século XX.

Automóveis mais baratos, capital nova, estradas asfaltadas, sistemas de crediário, canais de televisão emergentes, multiplicação de prédios de apartamentos, bancos para financiar a aquisição da casa própria, estímulos ao consumismo e à submissão feliz às regras do sistema. O novo grupo amador encena $A$ ponte, de Carlos Queiroz Telles, drama sobre namoros ousados, mocinhas de família e abortos. Em 1959, no espetáculo de Vento forte para papagaio subir, de José Celso, uma personagem cantarola sua vontade de voar com o vento e o refrão da canção vocaliza um $a$, aberto e descontraído; expressão lírica do desejo de liberdade e ampliação de horizontes, num texto ingênuo e autobiográfico sobre a relação interior-metrópole.

No espetáculo seguinte do grupo, agora chamado Oficina, $A$ incubadeira (também de José Celso, sob a direção de Amir Haddad), um jovem asmático arrebenta contra o chão a simbólica e pequena caixa morna (do título), exasperado pelas tensões familiares e pelo cerco carinhoso da mãe neurótica, asfixiante e superprotetora. A visão acanhada da forma teatral e das relações pequeno-burguesas não obscurece um vigoroso e tocante depoimento pessoal. O jovem grupo amador é premiado no II Festival de Teatros de Estudantes, ocorrido em Santos, no ano de 1959.

Segue-se a montagem de As moscas, de Jean-Paul Sartre (texto baseado no mito grego de Electra), dirigida por Jean-Luc Descaves, refletindo o momento de fascínio exercido pelo existencialismo e seus princípios de libertação dos valores burgueses e de aprofundamento de questões que inquietam jovens artistas e intelectuais. A especulação filosófica sobre as opções do indivíduo, em face dos imperativos de uma sociedade rigidamente institucionalizada, contribui para dar maior consistência às preocupações do emergente Grupo Oficina.

Em 1960, são encenados Fogo frio, de Benedito Ruy Barbosa, e $A$ engrenagem, roteiro cinematográfico de Jean Paul Sartre, adaptado por José Celso e Augusto Boal. O primeiro texto retrata a questão agrária do país, a pobreza do campesinato, as geadas do Paraná; o segundo denun- 
cia os mecanismos que garantem, permanentemente, a burguesia, militares, caudilhos e o imperialismo, o controle ditatorial no continente sul-americano e expõe a alternativa de libertação pela via revolucionária. No contato com o Teatro de Arena, dirigido por Augusto Boal, o Oficina amadurece seus instrumentos de captação da realidade social brasileira.

Em agosto de 1961, a nova Companhia de Teatro Oficina Ltda., já profissionalizada, inaugura sua casa de espetáculos com a novidade do palco central e platéias convergentes (o "teatro-sanduíche"), na Rua Jaceguai, 520. E redescobre as propostas do Group Theatre, grupo norteamericano (1931-1941), que adotou a produção cooperativada, as decisões administrativas e financeiras tomadas em equipe, a autonomia ideológica do repertório. Crítica da sociedade americana, a companhia praticou a lição de Stanislavski, adequando-a à nova realidade. O Oficina abre sua casa com a encenação realista-psicológica de um texto de Clifford Odets, $A$ vida impressa em dólar, a análise emocionada da frustração da classe média trabalhadora, empobrecida pela crise de 1929, em contraste com a ascensão de novos homens de sucesso, bem menos escrupulosos.

A densidade e a homogeneidade do trabalho stanislavskiano dos intérpretes já têm a marca do rigor de Eugênio Kusnet, que José Celso incorpora às montagens subseqüentes, ao mesmo tempo que amadurece como encenador.

Ainda em 1961, ano da renúncia do presidente Jânio Quadros, o Oficina monta José do parto à sepultura, de Augusto Boal, direção de Antônio Abujamra, reflexão irônica sobre a condição de subdesenvolvimento e dependência e sobre o sentido da existência e da participação. O esforço de captação do comportamento do homem brasileiro oscila entre o estilo mais emocional e psicológico do Oficina e a postura simplificada e crítica do Teatro de Arena, soma que resulta pouco definida.

Em 1962, as encenações de Um bonde chamado desejo, de Tennessee Williams, e de Todo anjo é terrivel, de Ketty Frings, retomam o gosto pela dramaturgia americana e a experimentação stanislavskiana; o desejo de crescimento e renovação engajada; o exercício de uma sensibilidade própria; uma forma de relação interpretativa com o público nacional que recusa os procedimentos da representação popular, tal como a entende o Teatro de Arena.

A montagem de Um bonde chamado desejo, dirigida por Augusto Boal, demonstra a atração do Ofícina pelo novo teatro norte-americano e pelo trabalho do Actors' Studio, perceptível nos desempenhos de muitos atores de cinema (Marlon Brando, Montgomery Clift, James Dean etc.) e nos conteúdos contestatários de filmes, como os de Elia Kazan e Richard 
Brooks, por exemplo, que retratam a face terrível da família de classe média norte-americana e de todo o american way of life.

Depois, o Oficina passa à escolha de peças soviéticas. A primeira é Quatro num quarto, adaptada por Eugênio Kusnet de A quadratura do círculo, de Valentin Kataiev, que satiriza o início da experiência coletivista soviética. O belga Maurice Vaneau dirige essa comédia de boulevard que atrai um grande público, graças ao humor acessível da chanchada e às brincadeiras e improvisações em cena.

\section{Identidade no quadro do realismo psicológico}

A partir de 1963, o Grupo Oficina acentua sua inclinação para o teatro de análise social e crítica, investigando em profundidade os mecanismos da interpretação psicológica. Pequenos burgueses torna-se a transposição de uma problemática estrangeira que visa a um reconhecimento de nossa identidade. Máximo Gorki, o autor da peça, é um militante revolucionário mais romântico que realista, mais idealista que pragmático, mais cristão que materialista. Socialista e crítico, massacrado, como nós, pelas condições periféricas do capitalismo na Rússia, czarista e bárbara: um país seduzido pelos modelos europeus, enquanto fervem as idéias revolucionárias, sob intensa repressão policial. No Brasil, em abril de 1964, os militares implantam a ditadura, depondo o presidente João Goulart.

O espetáculo revigora o realismo psicológico stanislavskiano e procura ser "fiel" à atmosfera crítica gorkiana. O "herói positivo", com quem os jovens de pretensões revolucionárias se identificam, é Nil, o ferroviário que confia no futuro e no potencial transformador do proletariado. Pequenos burgueses torna-se um sucesso, porque retrata e impressiona profundamente o público brasileiro: o nosso cotidiano comezinho está na cena, tão real e íntimo, que nos desconcerta. Eugênio Kusnet, interpretando o velho Bessemenov, é a encarnação de nossos pais ou de parentes próximos. Todas as personagens refletem pessoas muito conhecidas: suas discussões são as mesmas que travamos a todo momento, em família, nas universidades, nos bares, nos sindicatos, nas câmaras políticas...

Aprofundamento didático do retrato: o bode expiatório, a luta das classes 
Com o tempo, o retrato da pequeno-burguesia circunscrito ao quadro limitado do realismo crítico cansa o Grupo Oficina, que quer experimentar uma linguagem nova, mais abrangente, capaz de expressar a complexidade sociológica do mundo contemporâneo, que o direciona para o teatro épico de Brecht. O Oficina quer mostrar ao público os mecanismos que condicionam os conflitos no mundo moderno; mostrar a sociedade como algo dinâmico, conhecível e transformável; estimular o espectador a mudar a realidade social brasileira.

A peça escolhida é Andorra, de Max Frisch, um suíço anárquico e irônico até com a hipocrisia de seu próprio país, neutro, pacato e dissimulado. Discípulo de Brecht em muitos aspectos formais e técnicos, Frisch é um desesperançado dissolvente. Por isso mesmo, tem sua mensagem alterada pela montagem do Oficina, que rompe deliberadamente com o círculo vicioso, imutável ("porque os homens não mudam nunca") que o suíço propõe. O Oficina "historiciza" a parábola que Frisch propunha intemporal, num espaço simbólico. Andorra não é o país real que tem tal nome. A "historicização" da montagem, porém, aproxima-se de Brecht. Para tanto, o diretor acrescenta pantomimas e falas de outra peça de Frisch (Bidermann e os incendiários) e até distorce uma fala que, repetidamente, perpassa a encenação de Andorra: "Quando se tem mais medo da mudança do que do fascismo, o que é que se faz para mudar o fascismo?". No original, porém, Frisch usa, em vez de fascismo, desgraça. Misturam-se desempenhos stanislavskianos, psicológicos e arrebatados, aos críticos e distanciados, num espetáculo baseado em rigorosas convenções cenográficas alegóricas, didáticas, épicas, no uso simbólico do espaço do confinamento, dos figurinos e revendo dialeticamente as conotações morais das cores preto e branco.

A recuperação do pessimismo parece-nos mais adequada ao momento da montagem, quando vale mais resistir ao regime autoritário, em 1964, do que aceitá-lo como um fatalismo, como algo inerente à condição brasileira. Um momento que precisa ser contestado e superado, de caça às bruxas, bodes expiatórios, delações, inquéritos policial-militares e omissões criminosas de toda ordem. A peça de Frisch é uma hábil construção para demonstrar os mecanismos sociopsicológicos que engendram o bode expiatório, um tema caro ao teatro desde os gregos. Tomando como símbolo o anti-semitismo, é possível estendermos a compreensão às várias formas de segregacionismo contra índios, negros, comunistas, homossexuais etc.

A base filosófica da trama é o ensaio de Jean-Paul Sartre, Reflexões sobre o racismo, cujas teses Frisch verte para o "drama didático, sem doutrina”. A encenação resgata a atualidade da peça, escrita em 1958, de 
claras referências às perseguições, ao autoritarismo, ao anti-semitismo dos nazistas, e recorre à mistura de procedimentos realistas e épicos, em defesa dos direitos humanos e da democracia ferida. Frisch denuncia a participação dos cidadãos médios, chamados neutros, na produção do segregacionismo. Não são os grandes carrascos, nem as vítimas notórias que estão na cena. Não é o retumbante Tribunal de Nuremberg. Ao contrário, a ação se passa numa época meio indefinida da atualidade, numa pacata cidade da Europa Central, neutra, cristã, temente a Deus, amante do próximo, piedosa, que declara sua não-violência e diz rejeitar o anti-semitismo. Mas que colabora, por mecanismos defensivoprojetivos (medo, ambição, despeito, competição, ressentimento etc.), na construção do segregacionismo e entrega aos carrascos o bode expiatório. Hipócritas, esses "honrados" pequeno-burgueses andorranos justificam-se em longos monólogos individuais, que são contraditados pelos fatos, encenados em flashback.

Mais uma reflexão atual e oportuna sobre o comportamento obscuro, amedrontado e interesseiro da pequeno-burguesia brasileira, que desfila na "Marcha da Família, com Deus, pela Liberdade" e ajuda a "caçar bruxas" e bodes expiatórios, em 1964, em apoio ao conservadorismo e ao regime militar.

\section{Ampliação do quadro sociológico: a luta de classes}

Em 1965, José Celso traz da Europa um vasto material, que permite ao grupo visualizar, mais concretamente, as propostas de Brecht: programas, fotos, discos do Berliner Ensemble. Enquanto montam Os inimigos, de Gorki, os mentores do Oficina trabalham na tradução de $\mathrm{Na}$ selva das cidades e encomendam a de Galileu Galilei a Roberto Schwarz.

Em 1966, o Oficina retoma Gorki, com Os inimigos, que pretende materializar, na cena, a lição de Karl Marx sobre a luta de classes, entre explorados e exploradores. As personagens, burgueses industriais violentos ou entediados, operários leais, equilibrados e gentis, são esboços simplificados, sem a complexidade humana de Pequenos burgueses. Ao mostrar proprietários e empregados de uma fábrica de tecidos que se fecha, o Oficina fala de classes que não conhece em profundidade e isso se reflete na densidade do trabalho dos intérpretes. A grande co-produção com Joe Kantor inclui ampla pesquisa, atores convidados, vários assistentes, cunho crítico-historicista, alguma influência de Roger Planchon. Kusnet prepara os intérpretes; Chico Buarque, a trilha sonora, 
inspirada em canções e hinos russos e soviéticos. A direção ressalta, criticamente, as perspectivas da burguesia, suas tendências liberais ou autoritárias, seu tédio, sua violência, suas ambições. A análise sociológica, a partir de Os inimigos, se amplia, e o comportamento da pequenoburguesia deixa de ter enfoque prioritário nas encenações seguintes.

No "Programa" o grupo declara que quer

realizar um teatro vivo, ligado diretamente à realidade social. Acreditamos na necessidade de um diálogo verdadeiro entre espetáculo e público ... Sobre os problemas mais urgentes, mais contraditórios de nossa realidade cotidiana. Seja através de um estilo realista, nos preocupa fundamentalmente a desmistificação da realidade, a análise o mais em profundidade possível, de nossas contradições psicológicas, morais, econômicas, sociais, políticas etc. ... Nossa meta é a de atingir condições para um teatro popular, livre, ligado às mais autênticas tradições culturais de nosso povo...

O espetáculo pretende ser uma crônica histórica, mas resulta confuso, sobrecarregado de informação extratextual, com dados estatísticos sobre fome, desemprego, prisões e levantes, além de letreiros e fotos de época, em slides no fundo do palco, comentando, dialeticamente, o comportamento dos personagens, conforme recomendam Piscator e Brecht. O excesso de informação atordoa o espectador e, de certa maneira, atrapalha a compreensão do cotejo sociopolítico, econômico e cultural da Rússia czarista, em 1905, com o Brasil, de 1966. A cenografia exuberante, de Flávio Império, enche o palco com elementos de estilos conflitantes, incorpora dados da pop-arte e do kitsch.

A experiência polêmica, discutida, resulta profundamente saudável, porque seu experimentalismo ajuda a soltar amarras de purismos castradores, determina influências e abre novos caminhos para o palco brasileiro. A construção realista, linear, psicológica e dramática tradicional do texto de Os inimigos conflita com a vestimenta épica, narrativa, crítica, distanciada da encenação, que assume descaradamente as citações, o hibridismo, o dialógico, o metafórico, o excessivo, o barroco.

\section{Retrato cruel e satírico: subdesenvolvimento e dependência}

Em março de 1966, um incêndio destrói o prédio do Teatro Oficina, que é reconstruído com o apoio da classe teatral, de jornalistas, artistas, 
intelectuais, órgãos governamentais e graças ao sistema de repertório do próprio grupo, exibido no interior de São Paulo e no Rio de Janeiro.

Durante a temporada carioca, tranqüila e rentável, Luís Carlos Maciel orienta um laboratório de interpretação crítica; Leandro Konder debate com o grupo questões básicas do materialismo histórico e da dialética; o Oficina estuda a cultura brasileira, a Semana de Arte Moderna, preocupa-se com o gesto brasileiro, os traços fundamentais da identidade nacional; o bem-sucedido espetáculo Quatro num quarto torna-se um constante exercício de improvisações, até sobre fatos políticos de atualidade, permitindo irreverências de rompimento com certos esquemas consagrados de interpretação; redescobrem-se os procedimentos das chanchadas da Atlântida, dos trejeitos e da força comunicativa dos ídolos populares, com que a gente brasileira se identifica e se diverte. A idéia de montar Brecht, no entanto, persiste.

Está preparado o caldeirão de uma grande síntese antropofágica: a encenação de $O$ rei da vela, de Oswald de Andrade, polêmico, antológico, provocador, irreverente, debochado. Preciso e direto. Atual e oportuno. Mais do que tudo que se vira antes na cena brasileira. Escândalo e consagração nacional, o espetáculo-manifesto deslancha o movimento tropicalista, retomada, no plano da comunicação de massa, da "contribuição milionária de todos erros". O rei da vela, escrito em 1933, é o retrato cruel e crítico da nação brasileira, de nossa escabrosa situação de subdesenvolvimento e dependência do capital norte-americano. O casamento da burguesia industrial ascendente com a falida aristocracia do café faz nascer o novo pacto social dos anos 30, que atira o país na aventura desenvolvimentista patrocinada por Mr. Jones, policiada pelo estado e pelas condições que levam à ditadura de Vargas, a partir de 1937.

A todos estarrece a atualidade do texto e da montagem: nossa ascensão possível baseia-se na vela, símbolo da industrialização, da morte e da superstição: nossa "autonomia" possível é controlada a distância pelo imperialismo e por seus lacaios da burguesia repressiva. "Somos, como vós mesmos, um imenso cadáver gangrenado", advertem autor e encenadores ao público.

A caricatura da pequeno-burguesia está no intelectual Pinote, que vende sua retórica elogiosa aos poderosos. Símbolos de uma tradição nacional: o puxa-saquismo e o favor da autoridade. Está no Seu Pitanga, que aparece, literal e fisicamente, com a corda no pescoço, endividado, pedindo caridade em nome dos filhos famintos e da dignidade já perdida. Está nas secretárias que se sujeitam às torpes bolinações de Abelardo I, o burguês industrial e usurário. 
Mas está principalmente em Abelardo II, o subserviente, o médio que aspira ao alto e chicoteia os de baixo. Ele se diz socialista, mas age como fascista. Conforme a conveniência! Seu modelo é o patrão, que é o seu Primeiro. Ele é Abelardo... Segundo! É o reserva de uma equipe, cujas peças são infinitamente permutáveis, sob o controle do dourado Mr. Jones. Ele é o pequeno-burguês carreirista e disponível.

Ao final, o arrivista Abelardo I cai em desgraça e deve desaparecer, ele também um pequeno-burguês em sua origem, traidor de sua classe, de sua gente. Abelardo II ascende, herdeiro das velas, da mão de Heloísa, a aristocrata decadente. $\mathrm{O}$ que, para o plenipotenciário Mr. Jones, é um good business. Aqui, de novo, da ótica reveladora e implacável da chanchada e da farsa circense, a hipocrisia do pequeno-burguês ascendente identificada, sem retoques.

Soa a hora de expor, no palco, a cultura e o homem brasileiros, sem as intermediações da dramaturgia norte-americana, russa ou suíça, e das técnicas de encenação de Stanislavski, do Actors' Studio, do TNP de Roger Planchon ou do Berliner Ensemble. O progressivo engajamento do grupo nas lutas políticas do pós-64 exige o registro crítico do homem brasileiro em seu ambiente por meio de formas teatrais novas que recriem, criticamente, a tradição de nossos palcos e artistas populares. A agressividade, o deboche, a auto-ironia de Oswald de Andrade para com os impasses ideológicos do subdesenvolvimento dependente servem, magnificamente, às ansiedades do Oficina, que coloca em novos termos a dimensão modernista, revolucionária e anárquica, de um autor esquecido pela cultura oficial e livresca.

Superando a influência futurista, dadaísta e surrealista, atento ao conflito ideológico de sua época, Oswald adapta a visão marxista à experiência sensual e telúrica da brasilidade e à observação satírica feroz de nossas relações históricas e sociais de colonialismo e exploração. Assim, ele formula a base teórica, ambígua e poética, de uma postura crítica, devoradora e transformadora de todas as contribuições da miscigenação e do patrimônio cultural da humanidade, a que chamou "antropofagia"; alternativa de sobrevivência de um criador vigoroso, eclético, cidadão participativo até a aparente incoerência, cuja subjetividade compulsiva está indisposta com sua classe de origem, a burguesia; mas não está, vivencial e suficientemente, próxima da classe cuja ascensão exalta, o proletariado. A raiva oswaldiana satiriza a submissão, a mitologia nacional de obediência à Igreja, à moral sexual do estado burguês e seus privilégios; aspectos enfatizados na montagem do Oficina.

Impressionado pela força da ópera tragicômica de Gláuber Rocha, Terra em transe, poema fílmico desencantado com os esforços da es- 
querda e do populismo, o encenador José Celso encontra, na lucidez anárquica de Oswald, o antidogmatismo, o sentido positivo das rupturas, exaltante da persistência, da luta e da vida. A montagem de $O$ rei da vela exacerba sua teatralidade antiilusionista e antiburguesa; parodia todas as formas de espetáculo; ironiza o "grande teatro" serventuário da classe dominante; debocha de Shakespeare, Balzac, Freud, Proust, do academicismo "neutro", do socialismo nativo que conchava com a propriedade privada, das negociatas, da sexualidade e do tédio dos abastados.

O tratamento circense do $1^{\circ}$ ato explicita "o sistema da casa", as manobras do capitalista brasileiro, do usurário que leva os clientes ao desespero; eles saem de uma jaula, controlados pelo chicote de um domador, submissos e humilhados. Os opressores, Abelardo I e II, têm o rosto pintado, os trejeitos e a movimentação dos palhaços; as batidas do gongo, a alusão cenográfica de tenda e picadeiro, a trilha sonora evidenciam a metáfora circense. A sensualidade das cantadas e bolinações do patrão nas secretárias e a dissimulação diante da noiva Heloísa evocam o vaudeville. Abelardo explica-se brechtianamente ao público; seqüências inteiras, marcações e elementos cenográficos citam o espetáculo berlinense de Arturo Ui.

A Frente Única Sexual do $2^{\circ}$ ato revela os lazeres eróticos da burguesia, numa ilha paradisíaca da Baía de Guanabara, pelos procedimentos cênicos grosseiros e pornográficos do teatro de revista da Praça Tiradentes; satirizam-se o ufanismo, o verde-amarelismo, a mistura de relações libidinosas, econômicas e políticas. No alto, uma inscrição ufanista bilaquiana, freqüente nos compêndios escolares, reforça o clima da "espinafração": "Criança, não verás nenhum país como esse".

No terceiro ato, operístico, de influência glauberiana, agoniza o burguês: descartado pelo imperialismo, repassa ao substituto a mulher e os negócios; Abelardo I reconhece sua condição provisória de testa-de-ferro, latino-americano e tragicômico e as regras que determinam seu apogeu e sua queda; visualiza a possibilidade de transformação social revolucionária na fábula do vira-latas Jujuba, que abandona o conforto da caserna para se solidarizar com a cachorrada faminta das ruas, que os soldados espantam com a fuzilaria. Metáfora zoomórfica dos conflitos do autor, do encenador, do teatro, do povo brasileiro.

A pompa de La Bohéme, de Puccini, e Lo schiavo, de Carlos Gomes, e a alusão visual ao falso luxo das cortinas e franjas pintadas de dourado evocam a pobreza do nosso teatro de ópera; acordes da Marcha fúnebre (da morte do capitalista nativo) cedem lugar aos da Marcha nupcial, que consagra o casamento do emergente testa-de-ferro e a nova aliança com o imperialismo. 
Os intérpretes procuram captar o Gestus social, de classe, do brasileiro, e identificam claramente as manobras do imperialismo, da burguesia nacional, do marxismo soviético, do academicismo literário, do Partido Comunista Brasileiro, de todos os oportunismos e fisiologismos. O espetáculo incorpora a crueldade cênica dos programas televisivos do Chacrinha, música de mitos nacionais como Villa-Lobos e Carlos Gomes, canções folclóricas e exultórias paulistas e cariocas, modinhas carnavalescas, a Giovinezza fascista, a Internacional comunista, citações que vão de Bidu Saião a Gounod e Lamartine Babo. A simbologia fálica, as alusões sexuais e a interpretação paródica e provocativa, sugeridas pelo autor, são supervalorizadas no espetáculo e dão unidade aos tratamentos dos três atos. Destaque para o enorme boneco com um canhão no lugar do pênis.

As idéias de sexo e poder misturam-se constantemente; as vitórias de Abelardo sobre os devedores o excitam e ele as celebra, alegremente, com movimentos pélvicos de penetração sexual; afagos e coçadas na braguilha nos reportam aos hábitos, reais e bem conhecidos, de uma certa população masculina. Entre falas de cordial formalidade e conchavos políticos, as personagens friccionam-se da cintura para baixo. No final, a vela fálica de Abelardo II penetra o vencido e emasculado Abelardo I, marcando a ascensão daquele ao poder, como lacaio do imperialismo. Conotações de fallus impregnam os objetos de cena: o lápis, o sorvete, o canhão, o pedúnculo floral da bananeira, outro símbolo da nacionalidade. A observação crítica do cotidiano orienta a pesquisa livre dos atores para definir as funções sociais das personagens, seu caráter de classe, e para expor os gestos que lhes correspondem. Ironizam-se ainda os mitos nacionais: o intelectual Pinote, com chapéu, espada e seu fardão da Academia Brasileira de Letras; o índio dos Biscoitos Aymoré; a baiana verde-amarela, de balangandãs, abacaxis e colares. Não faltam os familiares sotaques dos imigrantes explorados e endividados: polacos, franceses, italianos. E a lamúria e a corda no pescoço do Seu Pitanga, que explicita a situação endêmica do povo brasileiro.

O espetáculo provoca, além do intelecto, a carnalidade do espectador e se torna tão agressivo que levanta polêmicas críticas, atrai ameaças de espectadores ofendidos e suscita preocupações defensivas do próprio elenco, que contrata guardas de segurança, em certo momento. A agressividade estética ultrapassa os limites da realidade brasileira e desorienta e incomoda preconceituosos críticos durante a temporada de $O$ rei da vela, na Europa. 


\section{O pequeno burguês não reage}

A montagem de Roda viva, musical de Chico Buarque, não é produzida pelo Grupo Oficina, mas é dirigida por José Celso, incorporando toda a experiência do seu conjunto, que absorve procedimentos de linguagem e material humano dessa encenação. Roda viva enfoca a ascensão de um jovem cantor popular suburbano, ingênuo e temente a Deus, promovido a ídolo de massas pela engrenagem da televisão. Sua humildade e sua vida particular são destruídas pela máquina de consumo, e ele acaba devorado pelas "macacas de auditório".

$\mathrm{O}$ texto inspira uma encenação polêmica e vigorosa, que alicerça a sensualidade, o humor grosso e o barroquismo de O rei da vela. Mas exacerba a agressividade dos atores contra o espectador. Dessacralizase a relação palco-platéia. O diálogo essencial não é o da cena, mas o que se passa na platéia, entre atores agressivos e espectadores assustados, sacudidos e insultados com palavrões. Espirra-se-lhes o sangue de um fígado bovino fresco no rosto e nas vestes, e a tendência dominante desse público pequeno-burguês é a perplexidade, a não-reação. Revide efetivo, quase nenhum. Algumas pessoas saem do teatro durante a função.

As platéias pequeno-burguesas que se acreditam progressistas e contestárias ficam melindradas com a visão pouco lisonjeira do espetáculo a respeito de seu imobilismo. Outras companhias se queixam do radicalismo da montagem; o Comando da Caça aos Comunistas (CCC), de radicais de direita, invade o teatro, espanca atores, destrói cenários e figurinos, em São Paulo e Porto Alegre. A censura proíbe o espetáculo.

Em 1968, Fernando Peixoto encena Poder negro, de LeRoy Jones, tendo superado sucessivos embates com a terrível censura que dificulta o andamento de dezenas de espetáculos e shows, ou os inviabiliza de vez. Poder negro expõe raivosamente as estratégias e propostas radicais de movimentos negros norte-americanos em resposta à violenta opressão branca; situação que Peixoto compara com a dos países do Terceiro Mundo, explorado pelo capital internacional. O encenador escreve um livro, Brecht. Vida e obra, dedicado aos companheiros do Oficina. Ele e

Renato Borghi querem montar Galileu Galilei.

\section{A encenação de Galileu Galilei: mastigação marxilar e autocrítica}


A garra antropofágica do Oficina recria, no Brasil, Galileu Galilei e, de maneira mais radical ainda, Na selva das cidades. Peças que são, sintomaticamente, metáforas da devoração entre homens, classes, culturas. Devoração da dignidade individual pela corrupção e pela violência do poder, das catalogações velhas e opressivas pelas dúvidas novas e libertadoras. Chega o momento de aproximar Oswald de Andrade e Brecht. Criadores personalíssimos, que desafiam as normas estabelecidas, de variada produção inovadora, brilho intelectual e indomada autonomia de pensamento, militantes da dialética marxista, críticos demolidores da passividade, da resignação, do tédio improdutivo, da hipocrisia religiosa e dos mecanismos de exploração capitalista. Ambos são pesquisadores do teatralismo popular e educativo e recusam os limites do realismo-naturalismo e da psicologia individualizadora.

Nas encenações do Oficina sobre os textos de Brecht, o binômio fidelidade-reinvenção volta a presidir pesquisa de novos símbolos teatrais, assimiláveis pelas platéias e aplicáveis, como modelos de análise social, ao momento repressivo por que passa o país. Recém-saído das montagens de exaltação antropofágica, debochadas e agressivas de $O$ rei da vela e Roda viva, José Celso supera os conceitos lukacsianos, devora rapidamente os procedimentos épicos consagrados e revitaliza a tradição brechtiana já firmada. Mas a recuperação da vitalidade de Brecht, que os diluidores pouco criativos fragilizaram, impõe novos procedimentos cênicos, compatíveis com a radicalização da onda contestatária brasileira próxima da promulgação do obscurantista AI-5.

O Oficina juntou grande soltura inventiva no trato com as recomendações épicas, em montagens como Andorra e Os inimigos, arrebentando cristalizações, abrindo horizontes. A montagem de $O$ rei da vela é um treino fecundo nesse processo de decodificação da realidade brasileira.

Do combate espiritual, metáfora do canibalismo ancestral entre Schlink e o jovem Garga, personagens de $\mathrm{Na}$ selva das cidades, o mais novo sai premiado com a sobrevivência, fortalecido com os valores protéicos dessa luta sem trégua, que exaure o mais velho, somente libertado de sua amargura existencial pelo suicídio. Também dão suporte à recriação antropofágica do Ofícina o título da peça e o tema da dominação espiritual das forças dos combatentes. Além das arrebatadoras alusões poéticas à luta e à devoração, como formas de contato e de sobrevivência entre animais da floresta primitiva, berço da humanidade.

A personagem de Galileu, um glutão que "não resiste a um vinho velho, a uma idéia nova", é também um devorador de descobertas alheias, de Copérnico, Kepler, Bruno, de todo o ideário do humanismo 
renascentista e do próprio telescópio holandês que ele aperfeiçoa e vende, como seu, sem explicar a origem do engenho. Artimanha, além de outras, que, somada à autoria das cartas aduladoras cínicas que escreve aos seus vigias religiosos, o aproxima dos jeitinhos de Macunaíma e de certas atitudes culturais brasileiras. A peça termina com Galileu devorando um ganso temperado com tomilho e maçã.

Brecht sempre considerou suas peças como libretos destinados às encenações, para serem experimentados sociologicamente, de acordo com análises concretas da realidade política de cada momento. A versão final de Galileu Galilei, "múltipla e polissêmica", devora assuntos e formas das versões anteriores, numa nova síntese, com argumentos mais precisos e significados atualizados e universais, em busca de uma eficácia e de possibilidades de aplicação analógica ao exame de fatos da história contemporânea. Brecht escreve uma cena final, em que Andrea Sarti conversa sobre bruxas com as crianças, e atravessa a fronteira italiana, levando os Discorsi, para divulgá-los na Holanda. Cauteloso, o dramaturgo recomenda, em diversas montagens, a exclusão dessa cena. Em outros momentos, ele inclui ou suprime falas e intenções em outra cena, a quatorze, que finaliza várias montagens (a do Oficina e a dirigida por Joseph Losey, com Charles Laughton). Assim Brecht procura contrabalançar a condenação a Galileu com uma certa possibilidade de seu gesto social (abjuração e trabalho secreto) ser válido, em determinada circunstância. A ocorrência de um incidente histórico e social relevante, num certo momento, pode engendrar associações de idéias, agregar significados e releituras surpreendentes da peça e das encenações. Por outro lado, Brecht é um exemplo produtivo da "mastigação marxilar" oswaldiana. Ele devora a experiência acumulada de seu tempo, remontando contribuições culturais contraditórias, para se fortalecer e empreender seu combate pela emancipação do proletariado.

Galileu Galilei é uma peça épica, distanciada, narrativa, com longas falas de argumentação dialética. A construção é equilibrada; o tom, contido, às vezes humorado ou grave. A montagem é, em geral, irônica, austera e disciplinada, mas tem uma brecha altissonante, anárquica, agitada, catártica. Um retrato muito próximo das ansiedades nacionais daqueles novembro/dezembro de 1968. A limpidez racional do espetáculo é atravessada por uma cena de inspiração artaudiana, a do Carnaval de Florença, na qual os jovens do coro recuperam, com menor intensidade, a emoção, o irracionalismo, a agressividade e outros procedimentos de Roda viva: invadem a platéia, falam e cantam nos corredores.

Os intérpretes de Galileu Galilei (Cláudio Corrêa e Castro), do monge Sagredo e do Cardeal Inquisidor (Othon Bastos) ou do papa Ur- 
bano VIII (Renato Borghi) expressam o rigor dos longos raciocínios. A cena do Carnaval de Florença, porém, por sua proximidade com a vigorosa e tradicional festa brasileira de libertação do corpo e dos sentidos, vai sendo ampliada ao longo das temporadas, até se tornar independente do espetáculo e virar a semente de uma montagem de José Celso, O carnaval do povo, de dez anos depois, feita em praças, terreiros e no Teatro Oficina.

Alegoria de toda a ambigüidade política contemporânea, Galileu Galilei não atualiza e revisa apenas a militância de Brecht e das esquerdas, mas também o procedimento político de todas as nacionalidades européias que, dilaceradas pela agressão nazista, empreendem, no pósguerra, rigorosas ou indulgentes avaliações da questão da resistência e das concessões, numa perspectiva ampla, e do colaboracionismo dos cientistas, num sentido mais estrito. No esforço de superação do trauma da guerra e do genocídio, os países recompõem os frangalhos da nacionalidade e as forças para o desenvolvimento, por meio de quadros administrativos capazes de empreendê-lo. Isto é, forças à direita, à esquerda, de centro; ex-resistentes e ex-colaboracionistas nos mais diversos níveis, todos interessados na reconstrução inadiável de uma nova vida.

O reducionismo marxista de Moscou agasta a percepção mais complexa de muitos intelectuais militantes, inclusive Brecht, porque não iluminam a dialética indispensável aos novos tempos de recuperação das nações humilhadas pela guerra e de tensões da deténte. As questões das responsabilidades coletivas, da "culpa alemã" e seus desdobramentos obsedam o país e o mundo; centenas de dramaturgos, diretores de teatro e cinema germânicos tentam metabolizar essa angústia, que quase se funde à própria identidade alemã, até hoje.

Galileu Galilei é uma obra extremamente amadurecida, mas sempre aberta a novas interpretações e novos tempos, dado o seu caráter de experimento sociológico, "modificável". Sua amplitude e complexidade decorrem de um processo de depuração, de teorizações sucessivas, ao longo de duas décadas, um enorme conjunto de reflexões detonadas pelos fatos polêmicos, processados a cada dia da história contemporânea: a ascensão do nazismo, a desintegração do átomo e as pesquisas de Niels Böhr, Otto Hahn e Fritz Strassmann, a evolução do calendário atômico e da tecnologia bélica, os Processos de Moscou, a Segunda Guerra Mundial, o bombardeio de Hiroshima e Nagasaki, o julgamento dos cientistas que colaboraram para o gigantismo da destruição, a reconstrução da Europa e o Plano Marshall, a Guerra da Coréia, a perseguição 
macartista, a culpa alemã , o sectarismo ideológico das esquerdas, a desmistificação do stalinismo.

Além dos recursos didáticos depurados, a peça está sensibilizada por uma experiência de vida real, atribulada e complexa. Na última versão, porém, o grande esforço de elogiar a razão está marcado pelo peso das várias tendências do pós-guerra e da deténte, que também abalaram a pretendida limpidez dos marxistas, no contato com questões éticas delicadas e polêmicas, para as quais a rigidez dos princípios doutrinários nem sempre indicam soluções seguras e satisfatórias.

A cena quatorze, penúltima no texto, derradeira em várias encenações, tanto do Berliner Ensemble quanto do Grupo Oficina, parece ter sido reescrita num clima social e psicológico bem diverso daquele das cenas anteriores, em que o primado racional exalta uma visão triunfante da verdade científica. O tom confessional e os argumentos permeiam o clima de inquietação atroz, de avaliação dilacerante das possibilidades de resistência e seus limites humanos, de sentimento de culpa e humilhação, em face dos recuos táticos e do relativismo das circunstâncias cruéis.

Mas Brecht não justifica Galileu para torná-lo familiar e empático; reforça a necessidade do estranhamento, para demonstrar que a desgraça do sábio não é natural, inexorável ou eterna. Mas histórica e superável, se houvesse ânimo pessoal e apoio coletivo para tanto. Galileu torna-se narrador e avaliador crítico de suas próprias opções morais e políticas passadas. Não são a moral e a psicologia que interessam ao dramaturgo, mas um modelo existente de organização social que as condiciona e que ele submete à meditação do público, na expectativa de que possa ser transformada.

Brecht faz progredir as reflexões marxistas acrescentando duas questões: a duvidosa utilidade do herói, numa sociedade marcada pela alienação e pelo autoritarismo, e a discutível tática da mentira oportunista, que subtrai ao povo o direito de conhecer verdades científicas socialmente relevantes, no seu processo de conscientização e libertação. Se o herói tem sentido (ou não) num país infeliz que precisa dele, na falta de outras condições de enfrentamento da opressão, que dizer do crime de ocultamento de verdades que são, precisamente, libertárias?

Na cena treze, ao saber da abjuração de Galileu, o discípulo Andrea Sartri o reprova, agressivamente, por ter salvado a própria pele, exclamado: "Infeliz do país que não tem heróis!". Ao que o mestre retruca: "Não, Andrea! Infeliz do país que precisa de heróis!". 
A questão provoca o raciocínio crítico dos cidadãos da platéia, diante dos quais Brecht acumula demonstrações da necessidade de transformar a sociedade. Mas a posição ingênua de quem imagina poder delegar ao herói (ou a meia dúzia deles) a tarefa da resistência à opressão e dos avanços democráticos revela a sua fragilidade, quando Brecht associa o problema a uma outra questão da ética socialista, também colocada por Andrea Sarti (cena quatorze), na fórmula "antes mãos sujas do que vazias". Ao receber a cópia secreta dos Discorsi, ele se surpreende e procura justificar uma solução astuciosa, revolucionária, de Galileu para enganar os poderosos e avançar em suas pesquisas. Num longo discurso, porém, o velho mestre analisa suas alternativas históricas, seu contexto social, desmistifica o heroísmo que lhe é atribuído e revela que não houve premeditação, mas tão-somente o medo da dor física da tortura que o fez recuar na divulgação da verdade libertadora, privilegiando a mentira obscurantista e antipopular. Uma traição irremediável à "finalidade da ciência que é a de aliviar a canseira da existência humana". Numa impiedosa autocrítica, ele reconhece uma cumplicidade criminosa, uma traição à ciência e ao povo. Mais do que estabelecer o julgamento nítido ou a condenação da figura-símbolo, Brecht abre uma luz mais ampla sobre a práxis contemporânea, suas múltiplas ambigüidades e a necessidade permanente da autocrítica e de novas formas de resistência à estagnação.

O sentido de oportunidade política da encenação paulista de Galileu Galilei explicita que a complexidade do texto não se esgota no julgamento ou na penalização do sábio, mas envolve uma rigorosa avaliação ética da finalidade democrática da ciência e a compreensão ampla da experiência sócio-histórica, com vistas a orientar uma práxis presente e futura, capaz de se autocriticar, de identificar erros e concessões e, sem justificá-los, reorganizar-se para uma nova investida transformadora do conhecimento científico e da sociedade.

\section{Brecht e Artaud: revolução e macumba}

A encenação do Oficina se exercita nos procedimentos épicos da interpretação, da cenografia, da música instrumental, dos coros, dos solos e outros efeitos de som, da iluminação, das projeções em tela, das inscrições literárias e ilustrações gráficas. Empresta-se peso idêntico, senão maior, à força do texto de Brecht e suas variações poéticas, germes propulsionadores de todas as articulações de linguagem posteriores, à 
historicização, ao distanciamento crítico, ao Gestus social, ao corte da ilusão e da empatia, e à função narrativa dos coros. De um lado, a montagem abebera-se nas fontes do teatro político, social, do didatismo, da palavra e da racionalidade. Mas energiza-se em momentos específicos com as contribuições extravagantes da irracionalidade do dadaísmo e do surrealismo, das imagens hipnóticas e provocadoras de transe de Artaud e seus seguidores Brook, Grotovski, o Living Theatre, e o próprio José Celso, em Roda viva.

Um casamento difícil e tumultuado, dadas as diferenças muito nítidas de origens e finalidades dessas duas estratégias estéticas, emblemáticas de uma crise filosófica mais ampla que tensiona o mundo contemporâneo e se manifesta também no teatro. $\mathrm{O}$ elenco busca constantemente a atitude crítica que rompe o ilusionismo. Há, porém, momentos isolados de interpretações stanislavskianas que são logo dialetizados por intervenções distanciadoras: elementos emocionais sublinham as teses que Brecht acaba deitando por terra, em reforço da percepção mais aguda das motivações sócio-históricas.

A cena da paramentação do papa Urbano VIII (Renato Borghi) é um exemplo perfeito de como José Celso amplia, com recursos cênicos próprios, as recomendações explícitas de Brecht, no tocante aos procedimentos do Gestus social, ao denunciar como o indivíduo, vestido simplesmente, sem os atavios da indumentária hierárquica, se afasta progressivamente de suas conviç̧ões pessoais, da amizade e da admiração intelectual que nutre pelo sábio subversivo. À medida que se lhe acrescentam os complementos da vestimenta papal, Urbano VIII sacrifica essa consciência individual e assume a atitude de chefe supremo de um sistema autoritário obscuro, capaz de ameaçar com a tortura.

Os cantos vitais dos coros enfatizam a diferença de linguagem e aparecem nitidamente separados das falas coloquiais comuns, interrompendo a ação, narrando os eventos, alterando os climas, assumindo o teatralismo; têm função de ruptura e não sublinham as falas e as ações, entram em conflito com elas, criticando-as, dialetizando-as. Imprime-selhes freqüentemente uma carga de ironia, caricatura e paródia. Procedimentos que um discípulo de Brecht, Peter Weiss, amplia no teatralismo exacerbado de Marat/Sade, cujas encenações projetam influências na montagem de Galileu Galilei, de José Celso, seja por uma certa caracterização do grotesco popular na emissão dos cantos e na movimentação paródica do coro, seja pelo clima circense-marcial das intervenções sonoras, pelo uso de instrumentos de percussão e efeitos eletrônicos ou ainda pela reutilização da enorme grade na boca de cena. 
E Artaud, como emerge diante desse fluxo criticista? De modo também crítico e condena, como equívocos reiterados e inutilidades, a arte e o pensamento do Ocidente, subordinados aos limites da percepção racional e da expressão de sentimentos e paixões pela palavra. Ele exalta a vitalidade estética e religiosa do teatro oriental, tal como o vê na Ilha de Bali, que preserva a essência tradicional da arte cênica. Privilegiando a expressão física do ator, mais ajustada à natureza dinâmica dos conflitos dramáticos, essa forma teatral aproximaria os homens, como nos rituais religiosos que liberam tensões reprimidas, medos e recalques, por meio de sessões de transe e hipnose, de magia e ritos encantatórios.

O Brasil também vivencia intensamente um conflito planetário. A equipe do Oficina está no vórtice das questões contraditórias de sua geração. O encenador manifesta tendências que irá fortalecer no futuro, na perspectiva do irracionalismo anárquico, do espetáculo sensorial, de toque físico, de choque e desenvolvimento, sem jamais perder a intuição política, que acrescenta ao prazer de uma libertação individual, cósmica, na esfera específica dessa possibilidade.

Como atender a tantas exigências de ocasião? Em Galileu Galilei, o encenador recua taticamente, disciplina suas convicções e seu temperamento e abre espaços específicos para as intervenções artaudianas no painel do espetáculo, regrado pela palavra, pela articulação intelectual, pelo roteiro do dramaturgo. José Celso escolhe a cena X do texto na praça do mercado, diante da multidão, em parte mascarada, saltimbancos expressam a visão popular da nova era, representando uma vigorosa alegoria poética, graciosa e irônica. Eles criticam a hierarquia da Igreja e a sociedade de classes, antevêem suas afirmações da astronomia de Galileu, o mata-bíblias, as possibilidades de uma inversão revolucionária de todas as relações sociais.

José Celso transforma recomendações artaudianas, fundindo-as às questões candentes da realidade brasileira, apropriando-se de elementos ritualísticos da macumba e do Carnaval. O conteúdo político e irreverente da cena do desfile das corporações de ofício reflete sobre o valor do trabalho e sobre as hipóteses revolucionárias sonhadas pelos saltimbancos. Tudo isso evoca a José Celso o conflito social entre as manifestações culturais das classes e das raças no Brasil, o confronto entre a "cultura dominante e a cultura dominada". Ele põe em cena o ritual da "roda" ou "corrente", prática usual de nosso sincretismo religioso que junta pessoas de mãos dadas em concentração profunda para produzir energia mental, transmitida aos intérpretes e espectadores. Ao mesmo tempo, ele procura carrear para a cena do Carnaval de Florença a mesma força ciné- 
tica e sensual que vê emanar dos corpos explodindo nos terreiros de macumba, nas quadras das escolas de samba e nos desfiles das grandes avenidas, durante o Carnaval. Festa contagiante, espetáculo inigualável, que parece ressuscitar Dioniso, sob o ritmo sincrético da etnia brasileira. José Celso quer impregnar a cena dessa energia que revitaliza, liberta e faz transcender, em alegria e beleza, a gente sofrida e sem privilégios da periferia. Ainda que por alguns momentos. Ópio do povo? Resposta simplista demais.

O cenário do espetáculo de Galileu Galilei expressa o cerceamento da liberdade, simbolizado por uma estrutura de madeira que representa uma prisão. Uma enorme grade ocupa, no início e no fim, o lugar do pano de boca e é suspensa quando necessário. Prisão e grade constituem uma referência visual inequívoca à situação do país. Seu despojamento, sobriedade e caráter demonstrativo direcionam a atenção do público para as ações que ocorrem dentro de seus limites. Dispositivo de arquitetura elementar programado para intensificar uma metáfora do presente.

São simples andaimes de madeira e servem ora como suportes das movimentações dos atores, que percorrem seus estreitos corredores, suas varandas, penduram-se neles, debruçam-se nos parapeitos, sobem e descem suas escadas verticais, fazendo esvoaçar as indumentárias de cânhamo; ora delimitam o lugar da representação, liberam uma ampla área central para a ação dos intérpretes e ressaltam um piso elevado sobre o palco como tablado de demonstrações. No fundo, há uma cortina ou um telão amplo de cor neutra.

A encenação de Galileu Galilei que no Brasil faz aflorar a reflexão brechtiana sobre a ética marxista em confronto com o autoritarismo nos conduz naturalmente à especulação sobre certos aspectos morais e políticos da tradição contestatária brasileira, estimulada, preponderantemente, pelo modelo stalinista e seu progressivo desgaste e superação. E acaba por retratar, numa desconcertante coincidência, às avessas, a realidade obscurantista que, à custa de alguns equívocos, nos servia de modelo. Pressionados pela violência da direita conservadora, nossos anseios e projeções utópicas elegeram um paradigma aparentemente oposto, o socialismo soviético, cuja existência real nos foi escamoteada pelos êmulos de Stalin. Acabamos descobrindo que o modelo almejado tem a mesma face sombria e violenta de quem nos açoita.

Paralelamente a sua obstinada militância antifascista, Brecht enfatiza a necessidade da autocrítica sistemática sobre a práxis revolucionária, tanto nos países capitalistas quanto na correção de rumos dos regimes socialistas já implantados. A encenação capta as possibilidades do texto 
e se serve dele para realizar uma reflexão crítica de dois aspectos de nossa cultura política e história recentes. Num plano mais claro e imediato, estão o espelhamento dos métodos e motivações da ditadura militar para atemorizar e submeter o pensamento político autônomo e renovador no Brasil e as possibilidades de uma resistência que recua, mas não desiste e avança, efetiva e sub-repticiamente.

Num plano mais sutil, a encenação engendra a necessidade de se rever uma prática, também personalista e autoritária, das esquerdas brasileiras e sua compreensão dos processos revolucionários, da própria realidade, do papel dos diferentes setores sociais, na transformação de nossa sociedade, dependente e colonizada.

De um lado, a encenação de Galileu Galilei identifica para nós a face de nossa esfinge opressora, a tradição autoritária das classes dominantes, seus argumentos e falácias. Mas, de outro, ela instiga uma revisão crítica, sem bravatas ou demagogias, sobre concessões, derrotas, fracassos e eventuais conquistas das esquerdas brasileiras e seus heróis discutíveis.

\section{A encenação de $\mathrm{Na}$ selva das cidades}

Ao montar Na selva das cidades, do jovem Brecht, em 1969, o Oficina encontra matéria espessa, turva e bruta, propícia a intensas experimentações, plasmando no palco as tensões culturais e políticas que afligem toda uma geração rebelde, na mais radicalmente bela, poética, violenta, contraditoriamente anárquica e disciplinada encenação brasileira das últimas décadas; uma das experiências socioestéticas mais polêmicas e estimulantes que pudemos presenciar.

As imagens de combate e devoração, mergulho interior, angústia e caos existencial, impossibilidade do entendimento pela linguagem e conseqüente sentimento de desestruturação energizam a cena e espelham fielmente as relações antagônicas e radicalizadas dentro do próprio Oficina: encaixar-se ou não num modelo conivente com o sistema institucional, que atormenta o protagonista Jorge Garga. Reproduzir e reiterar os modelos selvagens e desumanos do sistema capitalista ou não? Eis o drama, cujo cenário é um ringue de lutas, com seu quadrilátero elevado, suas cordas, seu gongo... Em volta... muitos destroços...

$\mathrm{O}$ texto representa influência e superação do expressionismo; a forma é desigual, sobrecarregada; o enredo, tortuoso; as intenções são 
rebeldes e anárquicas; as personagens, obscuras e ambíguas; há uma tensão permanente entre o conteúdo dramático exasperado e a forma épica embrionária; inclui temas relacionados com o Teatro do Absurdo, mas está impregnado de uma revolta combativa, darwinista, acuada num beco sem saída; acumula citações e imagens aterrorizantes e desagradáveis, personagens marginalizadas, violentas e brutais, irracionalidade, frustração, degeneração sexual, solidão, desenlace doloroso, perspectivas sombrias.

Brecht faz a passagem do pessimismo expressionista de sua juventude para o enfrentamento adulto das regras violentas de competição e sobrevivência, da moderna barbaridade, enquanto metáfora das relações psicossociais e sadomasoquistas da jovem República de Weimar (1918 a 1933). No começo do período, o país está humilhado pela derrota na Primeira Guerra Mundial e deve pagar as indenizações aos vencedores, que ainda lhe tomam territórios.

O quadro político e social é caótico e sofrido: a inflação aumenta, porque crescem a dívida externa e as indenizações; a economia não se recupera; há desemprego, greves, invasões de fábricas e palácios de governo. A corrupção mina as instituições e as consciências se vendem; os conflitos entre a esquerda e a direita são freqüentes; a Revolução Espartaquista é esmagada pelo exército de Hindenburg, que passa a governar o país por meio de decretos-leis. Líderes políticos são assassinados, como Karl Liebkneck e Rosa Luxemburg. Os radicalismos criam condições para uma guerra civil. Os abastados defendem energicamente seus privilégios.

A produção cultural reflete o caos, a violência, a humilhação, a descrença, o pessimismo, os homens enfurecidos, a exploração dos mais fracos, as imagens de luta e devoração, a mitologia do vampiro. Uma tradição cara aos alemães, especialmente aos expressionistas, que simboliza, na síntese monstruosa do homem e do morcego sugador, o individualismo doentio e destrutivo das relações humanas.

Sensibilizado por tudo isso, Brecht não vê os conflitos como manifestação histórica, concreta, da luta de classes. Sua fábula é calcada numa generalização abstrata, que nem se passa na República de Weimar, mas numa América mítica de dez anos antes, em 1912. A abrangência universalista aproxima os símbolos da metrópole e do campo, da civilização e da barbárie, da América e do Oriente, da juventude e da maturidade, da sobrevivência e da destruição, da espiritualidade e da carne. Num espaço contemporâneo, mas impreciso e antinaturalista. Em Chicago, o rico malaio Schlink, ressentido e solitário, tenta submeter à sua vontade a consciência de um homem. O que corresponderia, numa concepção tra- 
dicional e metafísica, à compra de uma alma, semelhante à que ocorre no mito faustiano de Goethe e de Marlowe, no qual um homem de ciência, brilhante, iluminado, vende-se ao Diabo em troca de juventude, sabedoria e prestígio. Vale dizer, sensualidade, fascínio e poder. O jovem Garga se recusa a vender sua opinião ao ricaço. $\mathrm{O}$ combate começa, arrastando a miserável família do rapaz, mãe, pai, irmã e a namorada, e os violentos capangas de Schlink, numa sucessão de violências físicas e psicológicas e transações comerciais e morais.

Em 1921, no entanto, energizado por sua jovem carnalidade, Brecht não abdica inteiramente da tradição (idealista e irracional) do vampirismo e da devoração e resgata o erotismo sadomasoquimo que obsedaram Sigmund Freud. Não conhecendo o instrumental teórico do marxismo ou da psicanálise, o jovem Brecht vivencia uma transição filosófica, que está fragmentada entre suas personagens; ele estrutura o conflito básico da peça como "uma luta inexplicável entre dois homens". (Ele está fascinado pelos espetáculos de luta que agradam a um imenso público popular.) E adverte o espectador para que não se esforce no entendimento das causas, mas que se empenhe em participar dos conflitos e julgue com cerebral imparcialidade os métodos e as habilidades técnicas dos contendores, reservando todo o interesse para o round final.

Brecht está entusiasmado com essa conquista formal vitalizante, e sua advertência inicial procura contrabalançar um envolvimento emocional ou uma desorientação do público, diante do fluxo dramático forte e terrível comprimido no enredo; recusa os efeitos deletérios e mistificadores do aturdimento excessivo dos espectadores nos dramas sentimentalistas; começa a esboçar o procedimento épico distanciador das vinhetas e inscrições literárias, que antecipam a informação resumida do conteúdo dramático das cenas.

Como nas primeiras peças de Brecht, mergulha-se no reflexo das influências de Rimbaud e Villon, de suas afinidades com os dramaturgos Büchner e Wedekind na fixação dos aspectos sombrios do comportamento humano, do crime, da sexualidade sem freios, da decadência; na galeria de marginalizados, vagabundos, bêbados, prostitutas, proxenetas, desviados sexuais; e num completo bas-fond.

A peça acaba sem dar respostas ao conflito essencial, constata impossibilidades, transe, impasse; provoca esse desconforto no espectador que não é nem sequer gratificado pela solução dramática de um confronto efetivo, palpável, definido, entre os dois contendores, que os aproxime ou destrua. A reserva de todo o interesse para o round final é, de certo modo, frustrada: não há combate, porque não há contato ou entendimento possível, nem pela linguagem, nem pela agressão ou pelo ódio. 
Alguns aspectos aproximam e distanciam o jovem Brecht de Hermann Hesse, alemães e contemporâneos, anárquicos e contestadores, testemunhas angustiadas e revoltadas da época niilista e caótica do expressionismo, ainda que reajam de modo pessoal, preconizando soluções culturais diversas. A saída espiritualista de Hesse, mesmo merecedora de atenção, é, para Brecht, uma alternativa sem sentido prático algum, tal como ele coloca numa fala de Jorge Garga. Brecht e Hesse rebelam-se diferentemente contra os valores competitivos e individualistas do Ocidente, a prepotência, a alienação, a pobreza das massas, o sofrimento humano. Brecht milita pela explicitação da luta de classes; Hesse revela-se no humanitarismo filantrópico, prudente nas declarações de cunho político, adversário da tecnocracia computada, antibelicista, dedicado às vítimas das guerras e à busca incansável da harmonia física $\mathrm{e}$ espiritual.

A encenação do Ofícina, em 1969, atualiza a concepção de Brecht, enfatizando as correspondências com as preocupações de autoconhecimento e avaliação da juventude rebelde dos anos 60 , do movimento da contracultura e do hippismo, que elegem Hesse entre os seus vários gurus.

Um dos elementos que tornam a montagem de $\mathrm{Na}$ selva das cidades tensa, provocante e atrativa é a radicalidade de sua especulação existencial, a sua temática filosófica da luta entre a perspectiva espiritual de Schlink e o pragmatismo simples e vital de Garga, entre o desejo de transcendência cósmica e a aceitação das regras do jogo do materialismo prosaico do capital, entre o espécime que perde o combate e se suicida e o sobrevivente que reage a todos os golpes baixos.

São questões candentes que obcecam os jovens da década de 1960, na definição de um projeto de existência pessoal e coletiva, seja para repudiar no todo ou aceitar, integral ou parcialmente, o modelo castrador, imposto por uma civilização enferma e destrutiva, incapaz de harmonizar as ansiedades prementes do corpo e do espírito, estimuladora da divisão esquizofrênica, que conduz à infelicidade. Como já denunciara Artaud.

Penetrando na densidade enigmática da obra, o encenador engendra imagens que dão consistência inteligível a esse momento autobiográfico transfigurado, a essa tese polêmica exposta por um gênio imaturo, sensível, em crise de transição entre o expressionismo neo-romântico de uma época niilista e a necessidade premente de pôr alguma ordem, pragmática, mesmo desfocada, nesse caos de humilhação e revolta. O espetáculo é um esforço do instinto e da inteligência que persistem em sobreviver, pela emoção, "ao horror e à corrupção dos tempos". O texto e a monta- 
gem de Na selva das cidades são uma afirmação dos instintos vitais. A encenação traduz bem a tensão não resolvida entre o conteúdo e a forma da peça; não escamoteia, com didatismos ou facilidades, essa contradição básica que sacode o espectador com o supernaturalismo carnal, despudorado e grotesco das personagens e situações, o lirismo sensual, alcoólico e panteísta de certas falas, em desacordo com a forma narrativa, embrionária de um teatro épico que amadurecerá depois.

A variedade de tratamentos estilísticos dados às cenas do espetáculo está baseada na configuração atípica da peça, subjetiva, visionária, deformadora da realidade, contaminada de expressionismo. Ela exorbita das catalogações simplistas e antecipa imagens oníricas, sensuais e mórbidas, e preocupações temáticas do Teatro do Absurdo: precariedade e derrisão da palavra, falta de comunicação, inexorável solidão do ser humano, sua decadência física e espiritual, existência sem sentido, identidade fragmentária, expectativas frustradas, contatos que não se efetivam, niilismo, inabitabilidade do planeta, putrefação, morte...

Se o conteúdo da revolta social do jovem Brecht e do espetáculo do Oficina, porém, tem a ver com Adamov, Arrabal ou Genet, guarda enorme distância do niilismo transcendental de Beckett e das irreverências de linguagem de Ionesco. A montagem de José Celso tem o vigor da combatividade em face do seu momento histórico e uma intenção terapêutica, reorientadora, grotovskiana, que visa à transformação do ser humano, à superação de impasses pessoais e culturais, cuja dimensão anárquica e fluida a afasta do modelo sociológico, marxista e didático, do teatro épico, já exercitado sob tensão interna na temporada de Galileu Galilei.

A peça não exalta nenhuma esperança construtiva, nem o desejo de transformar uma circunstância histórica. O pessimismo impregna quase todas as articulações; a condição humana e a sociedade selvagem e competitiva são vistas como arquetípicas, atemporais; a única nesga de luz é o apego animal, puro e simples, à sobrevivência, não importa o custo moral, afetivo, intelectual, humano; a ética, a individualidade, a autonomia da personalidade são inúteis e descartáveis na nova sociedade massificada, onde tudo já está "numerado, carimbado, selado e vendido". As regras selváticas de seleção natural, de confronto e sobrevivência são as mesmas da floresta primitiva, da aurora da espécie humana; nessa essência, a história não teria mudado o homem.

As marcas da rebeldia e da subjetividade criadora estão presentes na montagem de $\mathrm{Na}$ selva das cidades, em todos os planos: como expressão de revolta contra os tempos que correm e as regras sociais vigentes; como superação das formas repetitivas e servis às recomendações doutrinárias e técnicas de Brecht e do teatro didático; como rompimento do princípio de 
fidelidade ao universo abstrato, atemporal e sem saída do texto; como adequação dos métodos de depuração grotovskianos (à conveniência do grupo e da realidade brasileira), destituídos, porém, da visão santificante, de refração da sexualidade, de remissão de pecados. Nada aparece aqui que não tenha sofrido a filtragem obsessiva do encenador, afinado com a tendência mundial da arte contemporânea de misturar, dialogicamente, orientações diferenciadas.

\section{Historicização e escavação arqueológica}

Mas é a força do momento histórico que direciona o processo de identificação do Grupo Oficina com a amargura, a revolta e os impasses do jovem Brecht, associada a uma compulsão íntima que o leva a adaptá-los, livremente, ao seu tempo, gosto e público, sem se limitar ao arqueologismo e à fidelidade restrita ao clima impreciso e idealista do texto, desconhecendo quase cinco décadas de histórias, a evolução posterior de Brecht, a própria experiência cênica do grupo e a utilização eficaz de recursos historicizantes na comunicação com as platéias. Eles estão integrados na mistura vulcânica de procedimentos cênicos do espetáculo, a exemplo da faixa com a inscrição $A$ São Paulo, cidade que se humaniza, referência localizadora, topográfica, didática, comentando permanentemente as ações. O cenário de ringue, lixo e destroços, metáforas de lutas, evoca a paisagem paulistana, real, que está sendo destruída e reconstruída, vivamente impressa na retina do espectador.

A faixa irônica historiciza o combate metafísico da peça e associa a fábula de Brecht à violenta transformação urbana de São Paulo e à expressão da luta de classes mais ampla, à engrenagem econômica da industrialização, que empobreceu o campo e fez afluir para as cidades grandes massas humanas, em busca de novos horizontes e sobrevivência, como os Garga. A riqueza do café e da industrialização criou o décor da megalópole congestionada pelo trânsito, por viadutos, muralhas de alvenaria, espigões de concreto e vidro, vias expressas, moradias improvisadas e inóspitas; cidade poluída, tensionada pelas invasões de terrenos e expulsões violentas, pela criminalidade que se entranha no subproletariado crescente, pelas quadrilhas que se organizam. A cidade está repleta de imigrantes nordestinos, desempregados, camelôs, mendigos, prostitutas, pivetes abandonados e trombadões. 
A paisagem urbana de "ferro e lixo", as relações de corrupção e violência, a luta darwiniana pela sobrevivência, as imagens violentas de destruição e construção da rua próxima, do bairro mítico do Bixiga, da cidade amada, estão metaforizadas no pequeno espaço do Oficina, no cenário de ringue e destroços, síntese do lixo cultural de toda uma civilização bárbara e competitiva, de uma época decadente, de valores enganosos e apodrecidos. Nessa encenação "caótica" e "catastrófica", há uma sutil orquestração diária, um controle milimétrico na sucessão dos quadros, na violência crescente de cada round, na composição dos estilos interpretativos de Stanislavski, Brecht, Artaud e Grotovski e na movimentação anárquica dos atores que procedem ao quebra-quebra generalizado dos objetos de cena, lançados, perigosamente, de um lado ao outro, deixando o público tenso.

Esgotadas as possibilidades de contato, os lutadores arrancam as tábuas do piso do palco, escavam a terra que está embaixo, em busca das origens do homem e de suas possibilidades; retiram uma carcaça de boi e uma bandeira vermelha. São símbolos de uma escavação no passado do Grupo Oficina, de sua disciplina racionalista, de moços idealistas e bem-intencionados que sonharam, literalmente, com uma vida mais justa e igualitária para todos. Mas que agora revisam essa herança cultural para superá-la, dessacralizando-a como quer Grotovski e revitalizando-se para novas criações críticas, como querem Brecht e o grupo.

O encenador está mais à vontade diante de Na selva das cidades do que em face do rigor dialético de Galileu Galilei e pode dar largas ao seu temperamento nas experimentações sensoriais e paroxísticas, na produção abundante de imagens de desvario, poéticas, guinholescas, repugnantes e cheias de vida, sugeridas pelo jovem Brecht: a encenação de $\mathrm{Na}$ selva das cidades supera a de Galileu Galilei, ainda que aquele texto não se alce ao nível deste último.

As duas visões do dramaturgo não são excludentes, mas complementares: da crítica e superação do expressionismo, Brecht evolui para o marxismo. O Oficina também opera uma transformação ao abraçar primeiro a racionalidade de Galileu Galilei e, depois, o anarquismo de $\mathrm{Na}$ selva das cidades, refletindo as contraditórias ansiedades da época, e José Celso, por sua vez, encontrará novas oportunidades para transubstanciar o drama do astrônomo em sucessivas remontagens. O que não faz com $\mathrm{Na}$ selva das cidades.

A pesquisa interpretativa reavalia todo um passado e empreende uma autocrítica e uma síntese antropofágica das paixões dos encenadores pelos 
procedimentos artísticos e técnicos de Stanislavski, Brecht, Artaud e Grotovski; pelo pensamento de Sartre, Oswald de Andrade, Reich, Jung.

É o momento de realizar, segundo José Celso, "uma escavação arqueológica" nesse passado, mastigar todos os mitos, totens e tabus que mobilizaram, consciente ou inconscientemente, os mentores do Oficina na elaboração dos mais expressivos espetáculos brasileiros e nos seus posicionamentos como cidadãos. A equipe se propõe a destruir seu prestígio institucional e o estereótipo que ajudou a produzir de si mesmo; pretende se reformular; enveredar pela dolorosa investigação autofágica, porque intenta produzir uma obra de arte inédita, fascinante e iconoclasta, consoante às recomendações de Grotovski, cuja influência vivifica o teatro mundial naquele momento. O Oficina passa por um torturante conflito interior: desenvolve a nova compreensão nos ensaios vespertinos de $\mathrm{Na}$ selva das cidades e submete-se à mortificação, ao sistema de produção teatral rotineiro, comercial, do espetáculo de Galileu Galilei.

A equipe se sente castrada em sua criatividade e nas relações de produção artística que pretende adotar, pelas imposições de uma política multinacional para a área da cultura e pela consolidação de uma mentalidade capitalista de produção teatral e suas repercussões. A pesquisa de escavação arqueológica na vida de cada integrante da equipe e nos mitos da herança nacional resulta num espetáculo de oito horas que o grupo deseja apresentar; e o reduz a cinco horas, ainda excessivas para os padrões aceitos. Enquadra-se a liberdade de criar num modelo odiado de produção, que mutila o espetáculo e expõe a sua natureza de mercadoria vendável a ser consumida nas regras comerciais do chamado "teatrão". Cabe ao grupo decidir se recusa o público pagante habitual e a subvenção oficial, e aí se concretiza, no plano real, o conflito do protagonista, de $\mathrm{Na}$ selva das cidades, cuja recusa em vender sua opinião abre-lhe as portas para uma temporada infernal. O grupo que apregoa a rebeldia e se alimenta dela, para exibi-la, tem que se submeter à natureza passiva de certos hábitos.

Os condicionamentos profissionais da gente de teatro, dependente de bilheteria, confrontam-se, fatalmente, com os processos de pesquisa grotovskiana, de investigação pessoal, de quebra das máscaras de personagens. E mais: como trabalhar a contradição de grupo revolucionário, que depende de um "teatro burguesmente instituído"? Como combater um "teatro morto" e viver dele? Como criticar e odiar a relação patrão-empregado e trabalhar nela?

Em meio a dolorosas indagações, o espetáculo de Na selva das cidades transubstancia bem a proposta grotovskiana de fazer os atores despi- 
rem-se das máscaras das personagens e viverem a tensão presente que lhes abrasa o íntimo. Queiram ou não. O sofrimento ainda os mantém juntos na temporada, mas logo cada um tomará o seu caminho, em múltiplas investidas rebeldes.

\section{Conclusões}

Optamos por limitar aqui nosso recorte sobre o repertório do Grupo Oficina; não acompanhamos os projetos seguintes. À guisa de conclusão, dizemos que assim se inscreve o percurso antropofágico, rico e contraditório, do Oficina, que reflete bem a própria evolução tortuosa do Brasil, na segunda metade do século XX. O grupo faz emergir, no palco, os dramas nacionais de cada momento, por meio de textos oportunos e encenações comunicativas, que espelham os conflitos com vigor e familiaridade, esmiúçam questões dolorosas de nosso cotidiano, sutilezas de comportamentos sociais corriqueiros, que nos passam despercebidos e são denunciados pelo destaque simbólico da arte e oferecidos à análise do espectador. O prazer do grupo em se autoconhecer e transformar, no contato diário com platéias renovadas, soma-se às preocupações mais amplas de toda a cultura brasileira, produzida pela pequena burguesia urbana contestadora, motivada, historicamente, a fazer a análise crítica de seu próprio comportamento, de suas funções e perspectivas dentro do sistema sociocultural e político brasileiro. Muitos jovens da classe média, como os do Grupo Oficina, percebendo-se mais esclarecidos, comprometem-se, existencialmente, em fazer valer sua visão social e sua argumentação crítica, assumindo o papel de porta-vozes da imensa população do país. Maioria da qual se acham, porém, profundamente afastados.

Participação, engajamento, compromisso, reforma, revolução são palavras de ordem desse momento de irreprimível ânsia de transformação, que se reflete em todos os setores de inteligência brasileira e do mundo inteiro. O grupo detecta, na mais combativa dramaturgia universal contemporânea, a análise de problemas e perplexidades que também nos atingem; transpõe formas e conteúdos desse patrimônio cultural do século XX e nutre nossa experiência crítica, no confronto com as instituições obscuras que se fortalecem no país; ajuda-nos na compreensão das angústias presentes e torna palpáveis, no palco, as diversas conexões entre povos e culturas, como analogias de natureza catártica, impulsos racionais de agir e transformar a realidade, afinidades de temperamento artístico e estádios de reflexão política e social. 
Assim, na América dos anos de crise econômica de $A$ vida impressa em dólar, dos conflitos entre pais e filhos de Todo anjo é terrivel, na Rússia czarista de Pequenos burgueses e os Inimigos, na Andorra simbólica e indeterminada, na Itália conflituada de Galileu Galilei, vicejam confrontos socioculturais, análogos àqueles dramas pessoais e coletivos, que agitam o cotidiano brasileiro. Igualmente expressos com nitidez crítica, irreverência demolidora dos mais cínicos mitos nacionais, em $O$ rei da vela e Roda viva.

Nas primeiras encenações intuitivas de textos brasileiros, no enfoque realista-psicológico de $A$ vida impressa em dólar, Todo anjo é terrível, Um bonde chamado desejo e Pequenos burgueses, no barroquismo épico experimental de Os inimigos, na alegoria historicizada de Andorra, no criticismo antropofágico/operístico/circense de $O$ rei da vela e Roda viva, na salada mista de procedimentos brechtianos e artaudianos de Galileu Galilei, na síntese poética grotovskiana/reichiana/expressionista de Na selva das cidades, encontramos o traço comum da indignação contra a hipocrisia burguesa, a coisificação e o esmagamento do ser humano, a incompreensão da sexualidade, a prepotência do capitalismo e seus mecanismos abjetos, o cruel entredevoramento das classes.

Relembramos assim para as novas gerações dos projetos políticos daquela juventude dos anos 60 , com a viva emoção construtiva de quem fruiu esse momento protéico de análises radicais, de efervescência diurna e noturna; e que sabe que o futuro se faz também com a experiência, pois é sabido que o novo se alimenta da tradição para vitalizarse, mesmo quando a contradiz. Não se trata de saudosismo, a práxis de hoje difere da dos anos 60. James Joyce, porém, tem alguma razão ao dizer: "O passado não só não foi, como ainda não passou...". É preciso apreendê-lo e superá-lo. A revolução é uma tarefa de homens felizes, porque se conscientizaram da clareza de sua necessidade.

LIMA, R. N. de. The "Teatro Oficina" attend to the political moment. Trans/Form/Ação (São Paulo), v.24, p.9-40, 2001

- ABSTRACTS: Examination of the trajectory of Teatro Oficina de São Paulo (1958-1972), as regards its preoccupation with political activism. By means of plays like $\mathrm{O}$ rei da vela and Galileu Galilei, Teatro Oficina demonstrates its rare sensibility for grasping social anxieties of each historical moment, choosing the text which best expresses them.

- KEYWORDS: Aesthetics; Brazilian theater; Teatro Oficina. 